\title{
Pengembangan Game Edukasi Pengenalan Ekosistem Berbasis Mobile
}

\author{
Alfrina Mewengkang ${ }^{1}$ \\ Universitas Negeri Manado \\ e-mail: mewengkangalfrina@unima.ac.id \\ Irene R. H. Tangkawarow ${ }^{2}$ \\ Universitas Negeri Manado \\ Hendrik Kasehung ${ }^{3}$ \\ Universitas Negeri Manado
}

\begin{abstract}
ABSTRAK
Tujuan dalam penelitian ini adalah merancang Game edukasi pengenalan ekosistem pada mata pelajaran IPA SMP berbasis mobile yang nantinya akan dipakai dalam proses pembelajaran. Penelitian ini menggunakan metode pengembangan sistem Multimedia Development Life Cycle yang memiliki enam tahapan, yaitu Design, Obtaining Content Material, Assembly, Testing dan Distribution. Setelah melakukan uji coba maka peneliti mengambil kesimpulan bahwa game edukasi pengenalan ekosisten telah layak untuk digunakan pada proses pembelajaran dan telah sesuai dengan konsep perancangan produk, dan dari hasil pengujian yang telah dilakukan aplikasi telah berjalan dengan baik berdasarkan tujuan pengembangan dan tidak terdapat kesalahan yang terjadi saat pengoperasian aplikasi
\end{abstract}

Kata kunci: game edukasi, pengenalan ekosistem

\begin{abstract}
This study aims to design and built mobile-based educational game of introducing ecosystem in science subject in middle school that will be used in learning process. This research is using Multimedia Development Life Cycle (MDLC) framework include Obtaining Content Material, Assembly, Testing and Distribution. After testing, the authors concludes that the educational game of introduction of ecosystem has been feasible to be used in the learning process and has been in accordance with the concept of product design, and from the test results that have been done the application has been running well based on development goals and no errors occurred during the operation of the app.
\end{abstract}

Keywords: education game, introducing ecosystem

\section{PENDAHULUAN}

Game edukasi merupakan sebuah permainan yang telah dirancang untuk mengajarkan pemainnya tentang topik tertentu, memperluas konsep, memperkuat pembangunan, memahami sebuah peristiwa sejarah atau budaya, atau membantu mereka dalam belajar keterampilan karena mereka bermain.
Munculnya berbagai macam game, termasuk game edukasi juga dipengaruhi oleh semakin berkembangnya teknologi di sekitar kita (Widodo, $2011 ; 12$ ).

Perkembangan game di dunia semakin pesat, tak terkecuali di Indonesia. Game saat ini sudah menjadi alternatif hiburan bagi tua, muda, pria maupun wanita. Industri pengembangan game juga 
sudah menjadi suatu hal yang menjanjikan, terbukti dengan banyaknya perusahaan proses pembelajaran dengan konsep "Bermain sambil belajar". Untuk sebagian anak, kata "Belajar" akan terasa sangat menakutkan, sehingga diharapkan dengan adanya game pendidikan yang menarik ini, anak tidak akan menyadari jika yang dilakukannya itu adalah termasuk belajar dan anak akan menjadi senang dan mau belajar (Jasson, 2009 : 32).

Saat ini kebanyakan pembelajaran di sekolah masih digunakan metode pengajaran menggunakan media buku panduan, begitu pula dengan pembelajaran yang dilakukan di SD, SMP, ataupun SMA. Pada pembelajaran Ilmu Pengetahuan Alam (IPA) dikelas VII seperti pada materi ekosistem laut siswa seringkali jenuh karena hanya belajar melalui buku pelajaran yang hanya menampilkan teks dan gambar membuat siswa bosan.

Penggunaan simulasi dan game digital dalam proses pembelajaran dan penilaian diperkirakan akan meningkat selama beberapa tahun kedepan. Banyak prediksi yang menyatakan teknologi akan perubahan yang baik pada dunia pendidikan. Melalui sebuah game, para siswa dapat menjalani kegiatan belajar mengajar secara santai dan menyenangkan. Selain itu, game juga dapat membantu dalam pengembangan keterampilan siswa melalui proses bermain tersebuat, seperti urutan permainan, keterampilan verbal, visual kinetik dan aktivitas berbasis game lainnya.

Maka dari itu ada baiknya jika ada permainan yang juga sekaligus mambantu dalam kegiatan belajar mangajar. Dengan sebuah game edukasi tersebut, diharapkan para siswa lebih tertarik untuk belajar sambil bermain. Kebanyakan game edukasi telah dikembangkan masih belum membatu proses pembelajaran, karena materi yang dipakai pada game belum sesuai kurikum yang digunakan.contohnya pada mata pelajaran Ilmu pengetahuan Alam (IPA) SMP.

Pada kurikulum 2013 untuk SMP terdapat materi ekosistem yang mengajarkan siswa tentang lingkungan dan rantai makanan. Pengembangan game edukasi untuk materi ekosistem akan sangat membantu pada proses pembelajaran karena game memiliki tampilan yang menarik ditambah lagi dengan materi yang sesuai akan membuat siswa dapat belajar dengan cepat.

Pada penelitian ini yang menjadi fokus kajian penelitian adalah : 1) Game yang dikembangkan adalah game edukasi untuk mata pelajaran Ilmu Pengetahuan Alam; 2) Game yang akan dikembangakan dibatasi dengan materi Ekosistem; 3) Software yang dipakai pada pengembangan adalah Unity 3D; 4) Metode pengebangan sistem yang digunakan adalah Multimedia Development Life Cycle (MDLC).

Tujuan dari penelitian ini adalah Mengembangkan Game Edukasi Pengenalan Ekosistem dan satuan-satuan kehidupan pada mata pelajaran IPA SMP kelas VII.

\section{KAJIAN TEORI \\ Game}

Game adalah kata bahasa inggris yang berarti permain atau pertandingan, atau bisa diartikan sebagai aktifitas terstuktur yang biasanya dilakukan untuk bersenangsenang. Game adalah sesuatu yang dapat dimainkan dengan aturan tertentu sehingga ada yang menang dan ada yang kalah, biasanya konteks tidak serius dengan tujuan penyegaran. Dalam hal permainan game perlu adanya tantangan dan juga motivasi untuk membuat game tersebut 
menjadi menarik untuk dimainkan (Samsul, $2016:$ 7).

Game adalah kegiatan yang melibatkan keputusan pemain, berupaya mencapai tujuan dengan dibatasi oleh konteks tertentu. Game merupakan salah satu media hiburan yang paling popular untuk semua kalangan usia. Sejak pertama kali ditemukan sampai sekarang, teknologi game telah mengalami kemajuan yang terbilang pesat. Hal ini ditandai dengan Genre ini (Wifda, (2015: 6).

Game merupakan sebuah bentuk seni dimana pengggunanya disebut dengan pemain (player), diharuskan membuat keputusan-keputusan dengan tujuan mengelola sumber daya yang diperoleh dari kesempatan-kesempatan bermain (token) miliknya untuk mencapai tujuan tertentu. Video.

Game adalah bentuk game yang terinteraksi umumnya melibatkan media video dan audio, game merupakan aktifitas terstruktur atau semi terstruktur yang biasanya bertujuan untuk hiburan dan kadang dapat digunakan sebagai sarana pendidikan (Wahono, 2006).

Game sebenarnya penting untuk perkembangan otak, untuk meningkatkan konsentrasi dan melatih untuk memecahkan masalah dengan tepat dan cepat karena dalam game terdapat berbagai konflik atau masalah yang menuntut kita untuk menyelesaikannya dengan cepat dan tepat. Tetapi game juga bisa merugikan karena apabila kita sudah kecanduan game kita akan lupa waktu dan akan mengganggu kegiatan atau aktifitas yang sedang kita lakukan.

Game atau permainan adalah sesuatu yang dapat dimainkan dengan aturan tertentu sehingga ada yang menang dan ada yang kalah, biasanya dalam konteks tidak serius dengan tujuan refreshing (Zulfadli, 2010 : 6).
Sejak pertama kali ditemukan sampai saat ini, game telah melewati beberapa fase evolusi penting dimana yang berperan besar terhadap perkembangan game sudah semakini pesat sekarang ini. Game pertama kali dibuat pada tahun 1966 oleh Ralph Baer bersama dengan timnya yang berjumlah 500 orang yang terdiri dari para insinyur dan teknisi. Setelah sebulan bekerja keras, Baer berhasil menampilkan dua titik putih yang bekejar-kejaran dilayar. Pada tahun 1972 muncul nama baru dalam dunia game. Nolan Bushel mendirikan perusahaan Atari dan membuat game Arcade Pong. Pada era baru dalam perkembangan dunia game terjadi pada tahun 1988 yang didominasi oleh perusahaan Jepang. Nintendo yang awalnya hanya memproduksi mesin fotocopy, dengan video gam systemnya telah mencapai omset miliaran dollar. Setelah masa awal perkembangan game ini, dunia game telah mengalami beberapa fase game PC, fase game console, dan fase game online. Sekarang ketiga fase game tersebut sudah semakin banyak variannya dan masing-masing memiliki kelompok penggemarnya sendiri (Prastowo, 2014 : 14).

\section{Elemen Dasar Game}

Menurut Teresa Dillon (Halim, 2013:3) elemen-elemen dasar sebuah game adalah :

a) Game Rule

Game rule merupakan aturan perintah, cara menjalankan, fungsi objek dan karakter di dunia permainan dunia game. Dunia game bisa berupa pulau, dunia khayal, dan tempat-tempat lain yang sejenis yang dipakai sebagai setting tempat dalam permainan game.

b) Plot

Plot biasanya berisi informasi tentang hal-hal yang akan dilakukan oleh player dalam game dan secara detail, 
perintah tentang hal yang harus dicapai dalam game.

c) Theme

Di dalam biasanya ada pesan moral yang akan disampaikan.

d) Character

Pemain sebagai karakter utama maupun karakter yang lain yang memiliki ciri dan sifat tertentu.

e) Object

Merupakan sebuah hal yang penting dan biasanya digunakan pemain untuk memecahkan masalah, adakalanya pemain harus punya keahlian dan pengetahuan untuk bisa memainkannya.

f) Text, grafik dan sound

Game biasanya merupakan kombinasi dari media teks, grafik maupun suara, walaupun tidak harus semuanya ada dalam permainan game.

\section{Pengertian Edukasi}

Dalam kamus besar bahasa Inggris education berarti pendidikan, pendidikan berasal dari kata didik, atau mendidik yang berarti memelihara dan membentuk latihan. Sedangkan dalam kamus besar Bahasa Indonesia (1991) pendidikan diartikan sebagai proses pengubahan sikap dan tata laku seseorang atau sekelompok orang dalam usaha dan pelatihan. Pendidikan adalah sebuah proses pembelajaran yang didapat oleh setiap manusia, dalam hal ini adalah peserta didik, tujuannya adalah untuk membuat peserta didik itu paham, mengerti serta mampu berpikir lebih kritis. Pendidikan dapat dirumuskan sebagai tuntunan pertumbuhan manusia sejak lahir hingga tercapai kedewasaan jasmani dan rohani, dalam interaksi alam dan lingkungan masyarakatnya. Pendidikan merupakan proses yang terus menerus, tidak berhenti. Pendidikan dapat didapat secara formal maupun non formal. Pendidikan formal diperoleh dari suatu pembelajaran yang terstruktur yang telah dirancang oleh suatu institusi. Sedangkan pendidikan non formal adalah pengetahuan yang didapat manusia dalam kehidupan sehari-hari baik yang dialami atau yang dipelajari dari orang lain.

Edukasi adalah suatu usaha sadar dan secara terus menerus yang dilakukan pemerintah, keluarga, dan masyarakat untuk tujuan mengubah suatu individu menjadi berarah dan lebih baik, dalam segala aspek kehidupannya. Sugihartono (Dewi, 2012 : 8).

\section{Pengertian Game Edukasi}

Game Edukasi adalah permainan yang dirancang atau dibuat untuk merangsang daya piker termasuk meningkatkan konsentrasi dan memecahkan masalah. Game Edukasi adalah salah satu jenis media yang digunakan untuk memberikan pengajaran, menambah pengetahuan penggunanya melalui suatu media unik dan menarik. Game Edukasi dibuat dengan tujuan spesifik sebagai alat pendidikan, untuk belajar mengenal warna, mengenal huruf, matematika, sampai bahasa asing. Game dengan tujuan edukasi seperti ini dapat digunakan sebagai salah satu media edukasi yang memiliki pola pembelajaran learning by doing, berdasarkan pola yang dimiliki oleh game tersebut, pemain dituntut untuk belajar sehinggs dapat menyelesaikan permasalahan yang ada. Status game, intruksi, dan tools yang disediakan game akan membimbing pemain secara aktif untuk menggali informasi sehinggadapat memperkaya pengetahuan dan strategi saat bermain. Game edukasi unggul dalam beberapa aspek jika dibandingkan dengan metode pembelajaran konvesional. Salah satu keunggulan yang signifikan adalah adanya animasi yang dapat meningkatkan daya ingat sehingga anak dapat menyimpan materi pelajaran dalam waktu yang lama 
dibendingkan metode pembelajaran konvesional.Game edukasi adalah permainan yang digunakan dalam proses pembelajaran dan dalam permainan tersebut mengandung unsur mendidik atau nilai-nilai pendidikan. Game edukasi yang akan dikembangkan bergenre Adventure, dimana Handriyanti (Wifda,2015:7).

\section{Ekosistem}

Ekosistem adalah tatanan dari satuan unsur-unsur lingkungan hidup dan kehidupan (biotik maupun abiotik) secara utuh dan menyeluruh, yang saling mempengaruhi dan saling tergantung satu dengan yang lainnya. Ekosistem mengandung keanekaragaman jenis dalam suatu komunitas dengan lingkungannya yang berfungsi sebagai suatu satuan interaksi kehidupan dalam alam (Purwoko, 2012).

\section{Unity 3D}

Unity merupakan sebuah game engine yang dibuat oleh Unity Technology. Kelebihan unity dibandingkan dengan game engine lainnya. adalah kemampuan membuat game cross platform. Dengan unity $3 d$, game yang dibuat dapat dimainkan di berbagai perangkat seperti smartphone dan game consule. Unity sendiri dapat membuat berbagai macam game, seperti RPG (Role Playing Game), Shooter, Recing, dan sebagainya (Wahana Komputer 2014: 31).

\section{Android}

Android adalah sistem operasi berbasis Linux untuk telepon selular seperti smartphone dan tablet computer. Android menyediakan platform terbuka bagi para pengembang untuk menciptakan aplikasi mereka sendiri untuk digunakan oleh bermacam piranti bergerak. Awalnya, Google Inc. membeli Android Inc.

\section{Adobe Photoshop CS 4}

Adobe Photoshop, atau biasa disebut Photoshop, yaitu perangkat lunak editor citra buatan. Adobe Systems yang dikhususkan untuk pengeditan foto/gambar dan pembuatan efek. Perangkat lunak ini banyak digunakan oleh fotografer digital dan perusahaan iklan sehingga dianggap sebagai pemimpin pasar (market leader) untuk perangkat lunak pengolah gambar/foto Dianggap sebagai produk terbaik yang pernah diproduksi oleh Adobe Systems. Versi kedelapan aplikasi ini disebut dengan nama Photoshop CS (Creative Suite), versi sembilan disebut Adobe Photoshop CS2, versi sepuluh disebut Adobe Photoshop CS3, versi kesebelas adalah Adobe Photoshop CS4 dan versi yang terakhir (keduabelas) adalah Adobe Photoshop CC 2017. Photoshop tersedia untuk Microsoft Windows, Mac OS X, dan Msac OS; versi 9 ke atas juga dapat digunakan oleh sistem operasi lain seperti Linux dengan bantuan perangkat lunak tertentu seperti CrossOver.

\section{Audacity 2}

Audacity adalah sebuah aplikasi editor audio digital. Audacity dalam ketogori opensource yang dirilis di SourceForge.net Mei 2000. Audacity bersifat cross platform, dan dibuat menggunakan $w x$ widgets untuk menyediankan GUI yang hamper sama pada beberapa OS yang berbeda.

\section{Penelitian Terdahulu}

Beberapa penelitian yang terkait dengan penelitian ini sebagai berikut:

1. Nur Arif Anandhita (2014) dalam penelitian yang berjudul "Pengembangan Games Berbasis Unity 3D Sebagai Media Evaluasi Pembelajaran Musik Di SMP Negeri 4 Purworejo". Hasil penelitian 
menyimpulkan aplikasi yang dibangun berupa game Pembelajaran musik berbasis Unity $3 D$ yang dibuat menjadi aplikasi Portable dengan format exe dan dikemas dalam bentuk kepingan CD. Persamaan penelitian yang dilakukan oleh Nur Arif adalah sama sama bentuk penelitian penge Robnggama menggunakan Unity 3D. Perbedaan terletak pada metode pengembangan yang digunakan, Nur Arif Mengunakan $\mathrm{R} \& \mathrm{D}$ (Research and Development) sedangkan penelitian ini menggunakan $M D L C$. Materi yang disajikan juga berbeda.

2. Harly Yoga Pradana (2014) yang berjudul Game Pembelajaran Musikal Untuk Anak-Anak. Hasil dari penelitian ini adalah sebuah game pembelajaran untuk meransang musikasitas anak dalam bentuk game ini bertujuan unuk menghasilkanaplikasi pembelajaran dan perangsangan musikalitas anak dangan format .exe. Persamaan penelitian yang di lakukan sama-sama mengunakan metode Multimedia Development Life Cycle. Perbedaan terletak pada aplikasi yang di gunakan Harly mengunakan Adobe Flash CS6.

Sementara, hasil dari penelitian ini adalah sebuah Aplikasi Game Edukasi Berbasis Mobile untuk SMP dengan materi pengenalan Ekosistem Darat, Air, Buatan dan Klasifikasi ilmiah.Kelebihan Aplikasi yang di kembangkan oleh peneliti dapat di jalankan dalam platform mobile dan juga dapat di jalankan pada windows hanya dengan pengaturan proses building pada Unity.

\section{PEMBAHASAN}

\section{Concept (Pengonsepan)}

Perancangan game edukasi untuk SMP kelas VII berbasis Mobile dengan format
Apk. Deskripsi konsep aplikasi ini adalah sebagai berikut.

Judul : Pengembangan Game Edukasi Pengenalan Ekosistem Pada Mata Pelajaran IPA SMP Berbasis Mobile

Nama Aplikasi : Ekosistem : Anak SMP Kelas VII (Umur 12-14 tahun) Aplikasi ini memuat materi Ekosistem 1. Materi Ekosistem

2. Materi Komponen ekosistem

3. Satuan organisme dalam ekosistem

4. Interaksi antara komponen ekosistem Bentuk Aplikasi : Format Apk Ukuran Aplikasi : $180 \mathrm{Mb}$ Gambar : Menggunakan file berformat JPG dan PNG Audio : Audio yang dipakai diambil di google translate, Unity Asset Store, dan http://www.orangefreesounds.com

\section{Design (Perancangan)}

Pada tahap perancangan aplikasi ini peneliti melakukan perancangan storyboard dan desain struktur navigasi berupa hirarki menu.

\section{Perancangan Storyboard}

Storyboard merupakan visualisasi ide dari aplikasi yang akan dibangun, sehingga dapat memberikan gambaran dari aplikasi yang akan dihasilkan. Storyboard dapat dikatakan juga visual script yang akan dijadikan outline dari sebuah proyek, ditampilkan shot by shot yang biasa disebut sebagai istilah scene.

Hirarki Menu

Sistem navigasi yang digunakan adalah komposit/campuran, sebab stuktur ini dapat membarikan interaksi yang lebih tinggi, sehingga pengguna dapat melakukan navigasi dengan bebas dapat dilihat pada Gambar 1. 


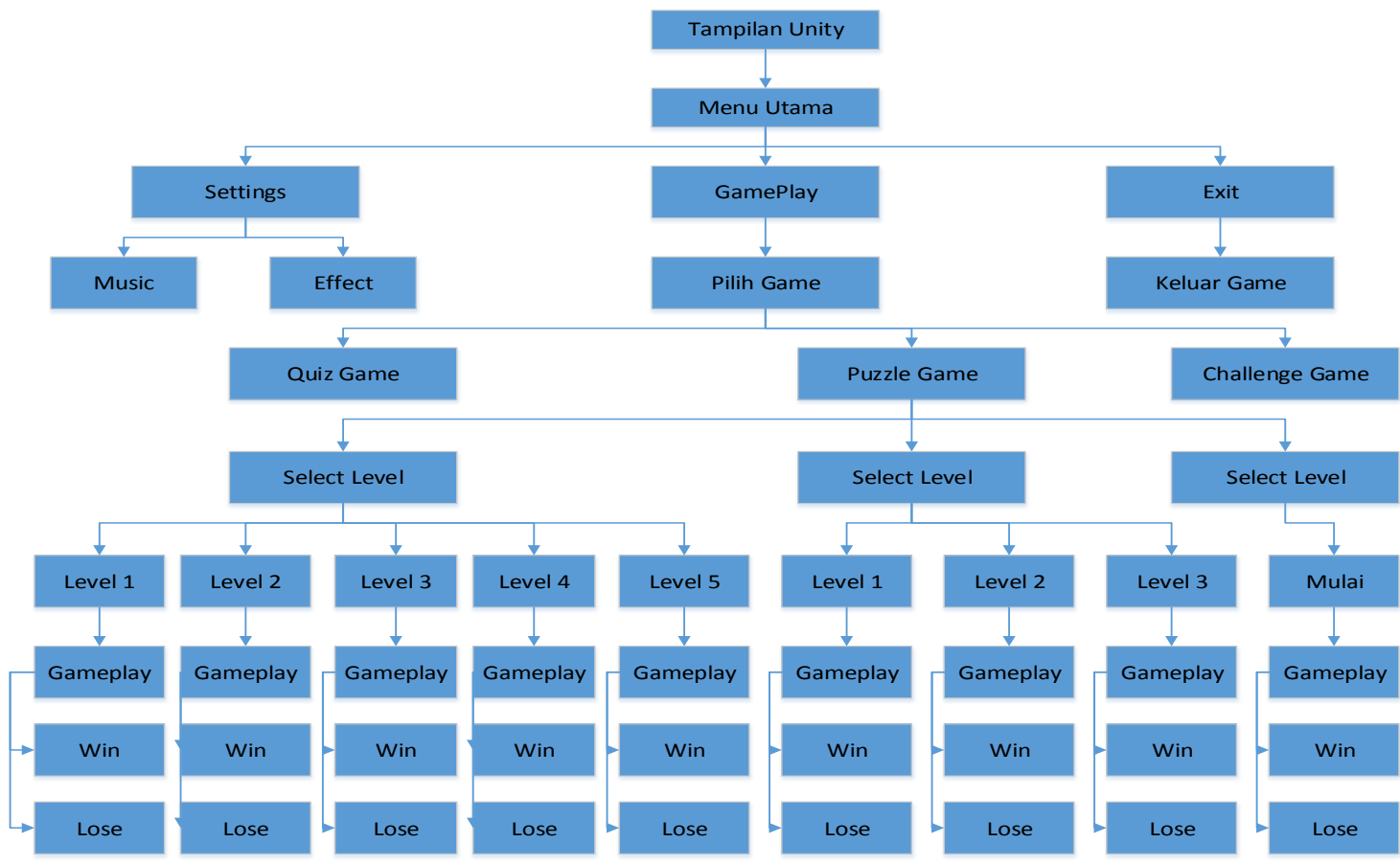

Gambar 1 Hirarki Menu

\section{Obtaining Content Material}

Pengumpulan material atau bahanbahan berupa skript, gambar, animasi, dan Audio. Diambil dengan cara mengambil dari berbagai sumber dan dibuat sendiri oleh penulis.

a) Teks

Skript Untuk aplikasi penulis peroleh dari situs http://answers.unity3d.com. Sedangkan script lain penulis membuat sendiri. Untuk materi pada game peneliti mengambilnya dari Jelajah BIOLOGI kelas VII SMP dan internet.

b) Gambar

File gambar pada aplikasi sebagian besar diambil dari internet dan untuk gambar lain dibuat sendiri oleh penulis.

c) Audio

Pada aplikasi audio yang dipakai penulis mengabilnya pada unity asset store, goole translate, http://www.orangefreesounds.com.
Spesifikasi perangkat lunak dan perangkat keras

Untuk Pembuatan aplikasi game edukasi untuk Ekosistem dan klasifikasi ilmiah ini dibutuhkan spesifikasi perangkat lunak dan perangkat keras sebagai berikut.

a) Spesifikasi Perangkat Lunak

Untuk membangun aplikasi ini menggunakan spesifikasi perangkat lunak sebagi berikut :

1. Unity $3 D$ versi 2017.2.0f3, digunakan sebagai engine tempat aplikasi dibangun.

2. Adobe Photoshop cs4, digunakan sebagai perangkat lunak untuk membuat desain background, desain tombol dan lainnya.

b) Spesifikasi perangkat keras

Untuk membangun aplikasi ini peneliti menggunakan perangkat keras sebagai berikut.
1. Processor AMD APU E2-2000 dual-core $1.75 \mathrm{GHz}$
2. Grafis AMD Radeon HD 7340 
A. Mewengkang ${ }^{1}$, I. R. H. Tangkawarow ${ }^{2}$, \& H. Kasehung ${ }^{3}$

3. $4 G B D D R 3$

4. $500 \mathrm{~GB} H D D$

5. 14.0" WXGA, HD Color Shine LED $1366 \times 768$ Piksel

\section{Pembuatan Menu Utama}

Dalam pembuatan menu utama peneliti mengambil background dari internet. Awal pembuatan yaitu masukan Canvas (dapat dilihat pada Gambar 2).

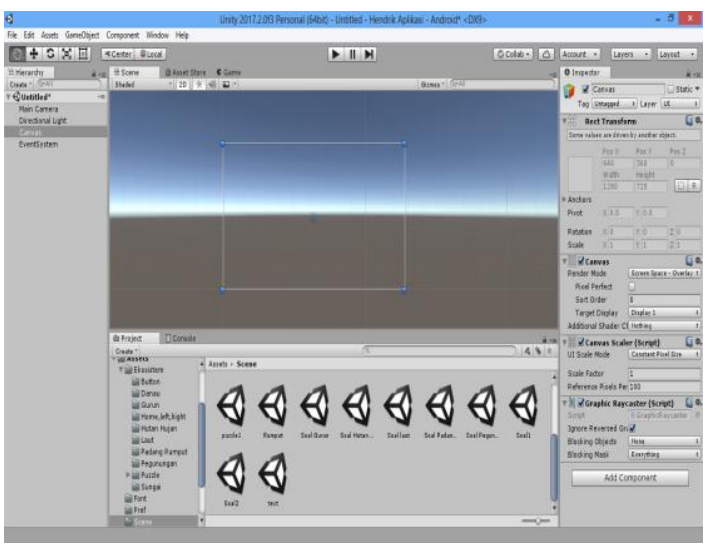

Gambar 2 Tambah Canvas

Selanjutnya tambahkan image dan background aplikasi yang telah diambil di internet pada Gambar 3 adalah tampilan awal background game.

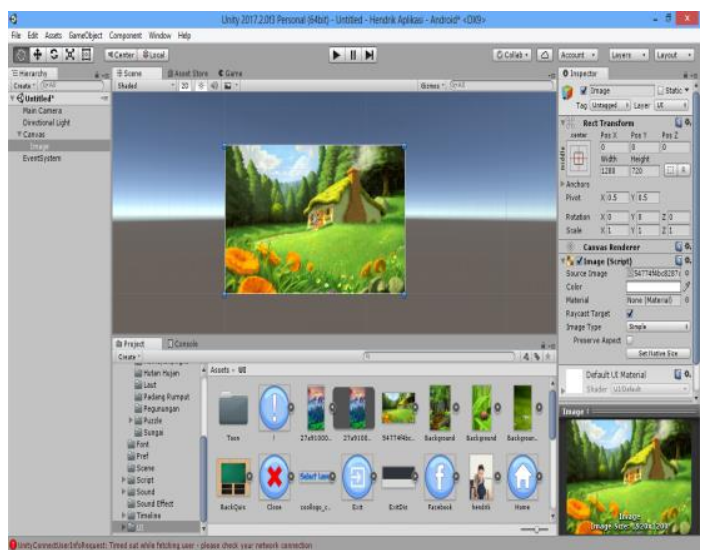

Gambar 3 Tampilan awal background game

Selanjutnya tambahkan 3 tombol yaitu tombol Gameplay, Settings, dan exit.
Jurnal Sains dan Teknologi, Universitas Negeri Manado http://ejournal.unima.ac.id/index.php/efrontiers

Untuk tampilan dapat dilihat pada Gambar 4.

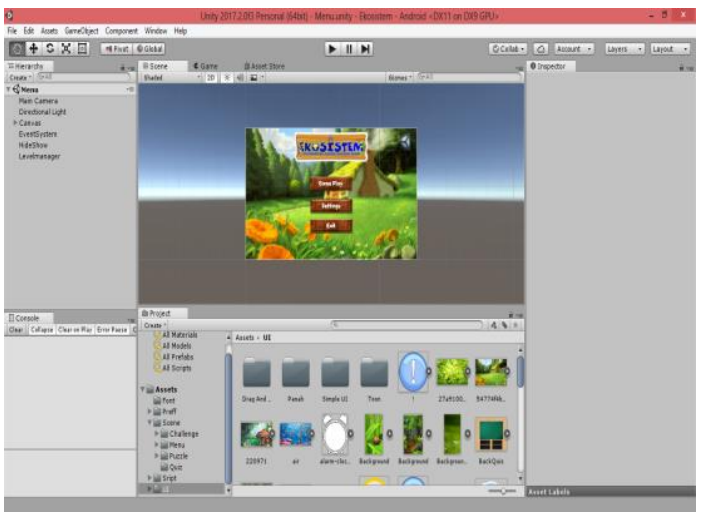

Gambar 4 Tampilan awal game

\section{Pembuatan Tampilan Pengaturan}

Dalam pembuatan tampilan pengaturan peneliti membuat tampilan yang sesuai dengan rancangan storyboard yang dapat dilihat pada Gambar 5. berikut adalah tampilan pengaturan.

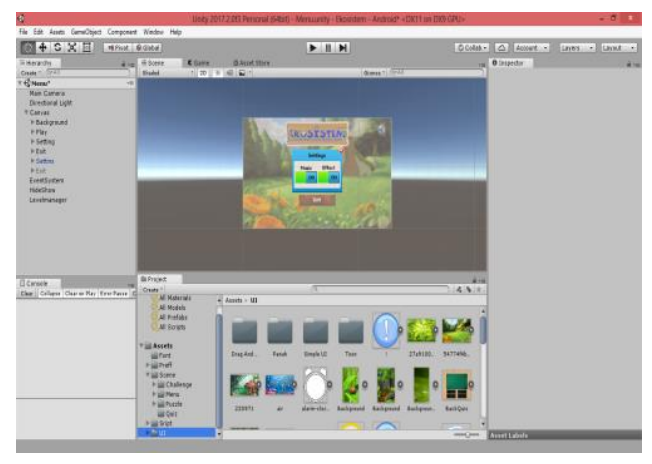

Gambar 5 Tampilan Pengaturan

\section{Pembuatan Tampilan Pilih Game}

Dalam pembuatan tampilan pilih game membuat tampilan yang sesuai dengan rancangan storyboard yang dapat dilihat pada Gambar 6 yang akan terdapat 4 tombol quiz game, puzzle game, challenge game dan home. berikut adalah Pilih Game. 
A. Mewengkang ${ }^{1}$, I. R. H. Tangkawarow ${ }^{2}$, \& H. Kasehung ${ }^{3}$

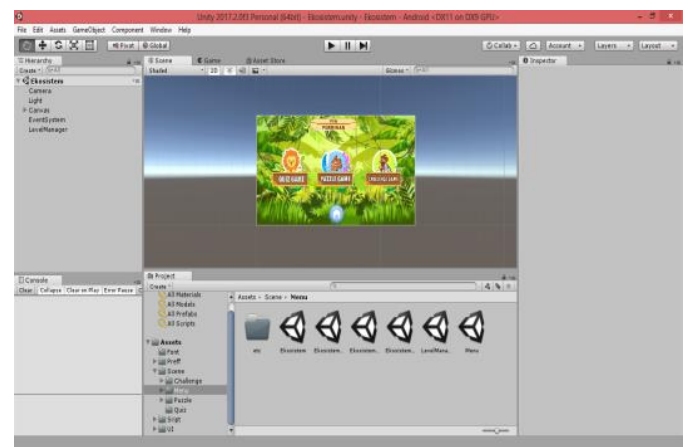

Gambar 6 Tampilan Profil

\section{Pembuatan Tampilan Select Level Quiz.}

Dalam pembuatan tampilan Select Level Quiz peneliti membuat tampilan yang sesuai dengan rancangan storyboard yang dapat dilihat pada Gambar 7 berikut adalah tampilan Select Level Quiz.

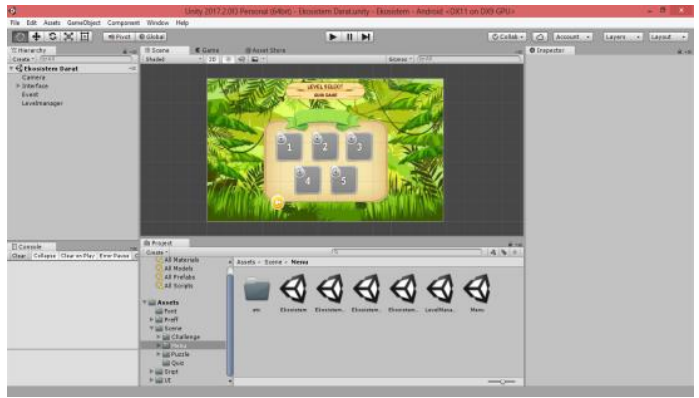

Gambar 7 Tampilan Select Level Quiz

\section{Pembuatan Tampilan Select Level Puzzle}

Dalam pembuatan tampilan Select Level Puzzle peneliti membuat tampilan yang sesuai dengan rancangan storyboard yang dapat dilihat pada Gambar 8 berikut adalah tampilan Select Level Puzzle.

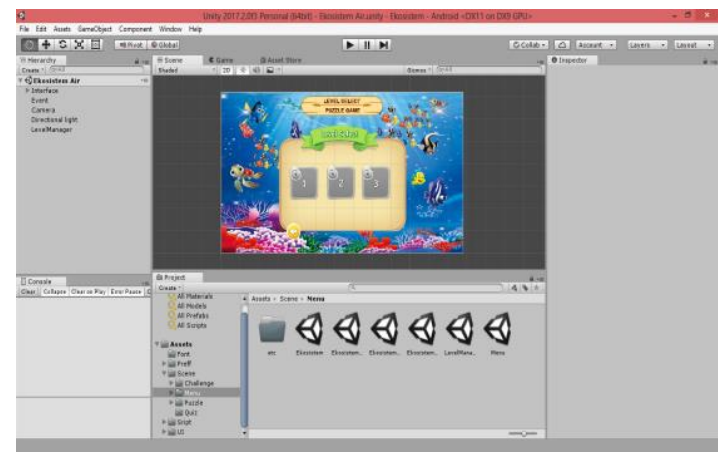

Gambar 8 Tampilan Select Level Puzzle
Jurnal Sains dan Teknologi, Universitas Negeri Manado http://ejournal.unima.ac.id/index.php/efrontiers

\section{Pembuatan Tampilan Select Level Puzzle}

Dalam pembuatan tampilan Select Level Puzzle peneliti membuat tampilan yang sesuai dengan rancangan storyboard yang dapat dilihat pada Gambar 9 berikut adalah tampilan Select Level Puzzle.

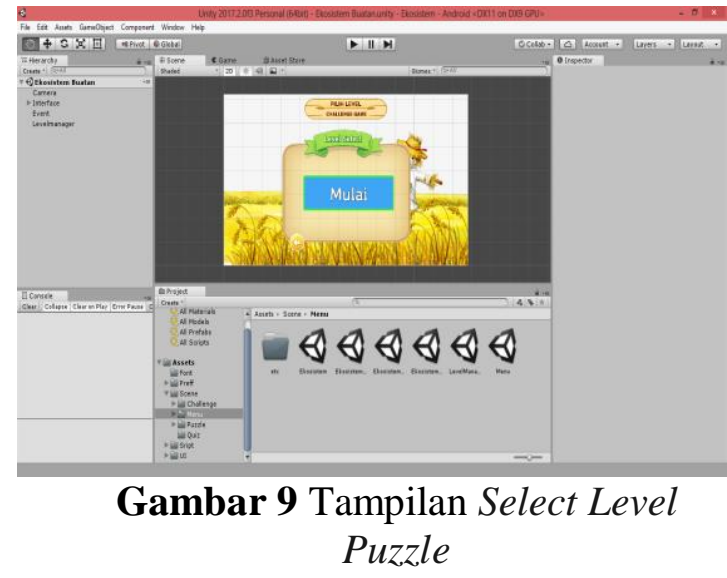

Pembuatan Tampilan Gameplay Quiz

Dalam pembuatan tampilan Gameplay Quiz peneliti membuat tampilan yang sesuai dengan rancangan storyboard yang dapat dilihat pada Gambar 10 berikut adalah tampilan Gameplay Quiz

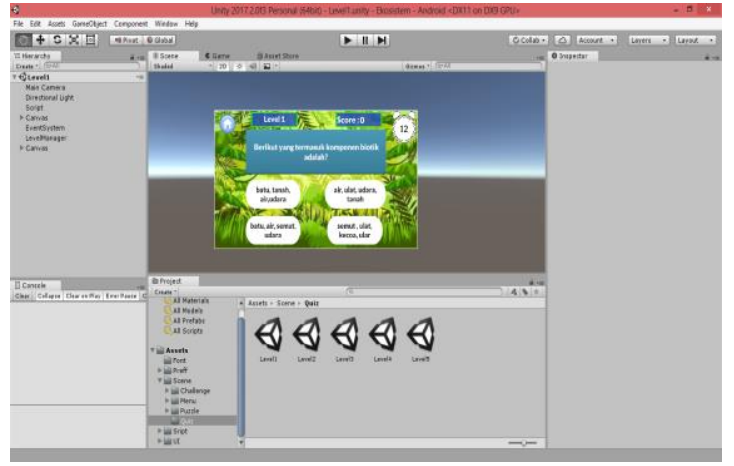

Gambar 10 Tampilan Quiz

Pembuatan Tampilan Gameplay Puzzle

Dalam pembuatan tampilan Gameplay Puzzle peneliti membuat tampilan yang sesuai dengan rancangan storyboard yang dapat dilihat pada Gambar 11 berikut adalah tampilan Gameplay Puzzle. 
A. Mewengkang ${ }^{1}$, I. R. H. Tangkawarow ${ }^{2}$, \& H. Kasehung ${ }^{3}$

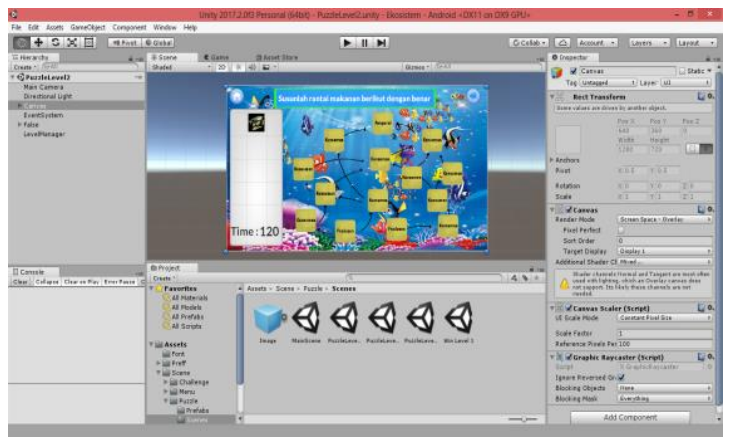

Gambar 11 Tampilan Gameplay Puzzle

\section{Pembuatan Tampilan Gameplay Challenge}

Dalam pembuatan tampilan Gameplay Challenge peneliti membuat tampilan yang sesuai dengan rancangan storyboard yang dapat dilihat pada Gambar 12, 13, dan 14 berikut adalah tampilan Gameplay Challenge

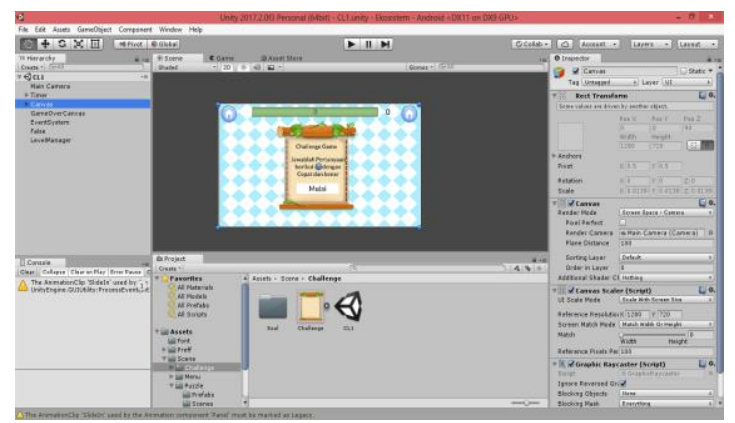

Gambar 12 Tampilan Gameplay Challenge

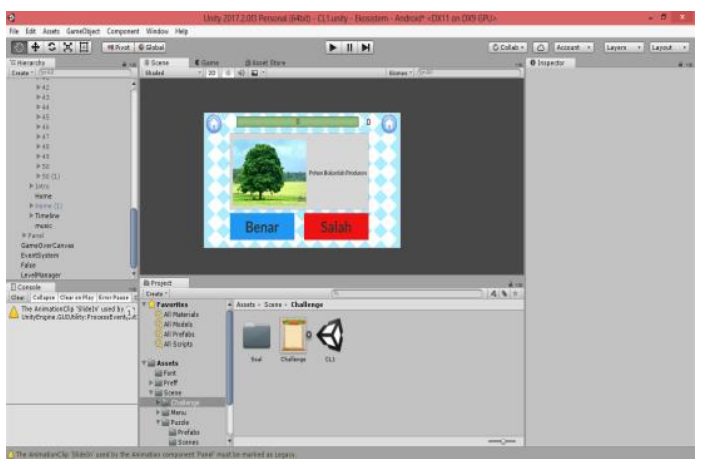

Gambar 13 Tampilan Gameplay Challenge
Jurnal Sains dan Teknologi, Universitas Negeri Manado http://ejournal.unima.ac.id/index.php/efrontiers

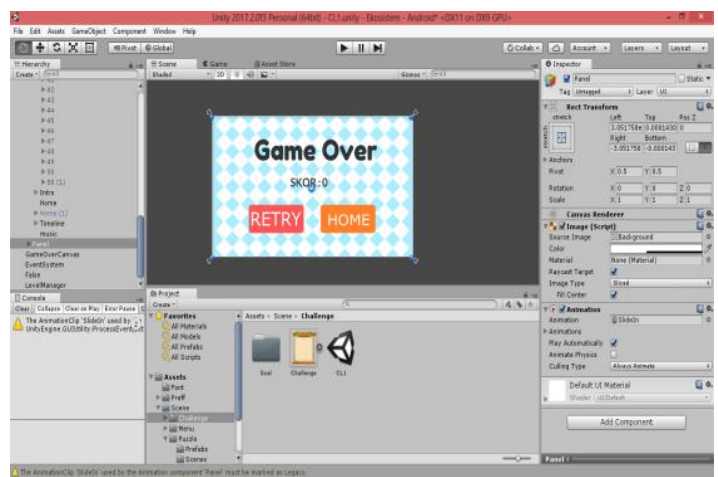

Gambar 14 Tampilan Gameplay

Challenge

\section{Pembuatan Tampilan Kalah}

Dalam pembuatan tampilan Kalah peneliti membuat tampilan yang sesuai dengan rancangan storyboard yang dapat dilihat pada Gambar 15 berikut adalah tampilan Kalah.

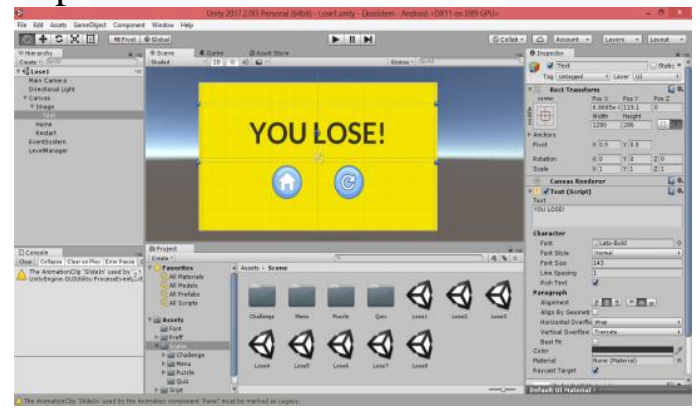

Gambar 15 Tampilan Kalah

\section{Pembuatan Tampilan Menang}

Dalam pembuatan tampilan Menang peneliti membuat tampilan yang sesuai dengan rancangan storyboard yang dapat dilihat pada Gambar 16 berikut adalah tampilan Menang.

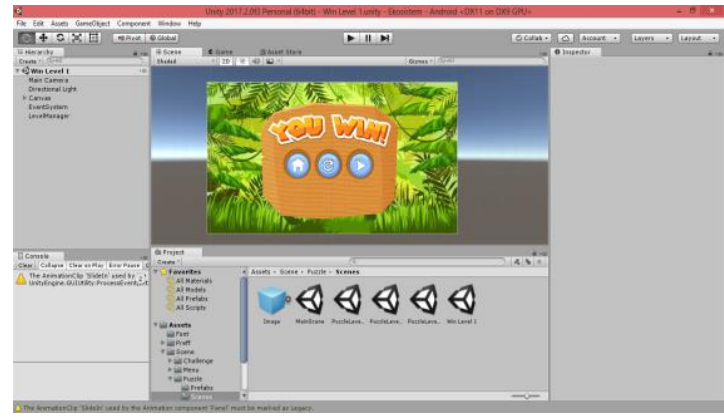

Gambar 16 Tampilan Menang 
Setelah melalui beberapa tahap produksi dengan melakukan engine dengan unity maka peneliti melakukan pengaturan build aplikasi untuk mobile pada unity (dapat dilihat pada Gambar 17). Untuk tampilan Interface dan Code akan ditampilkan pada Lampiran.

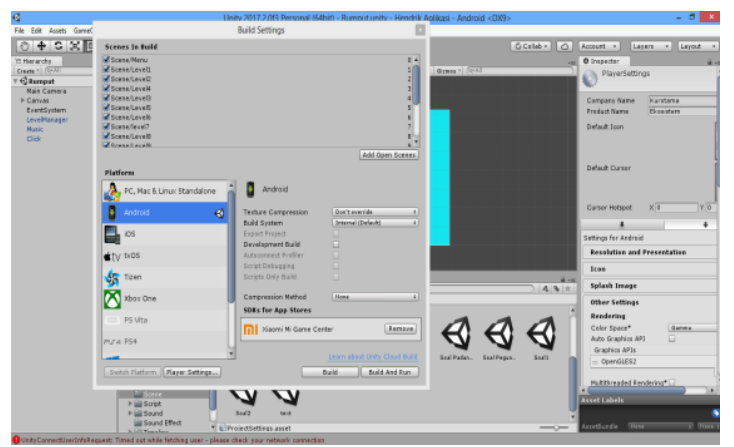

Gambar 17 Build Application Proses

Dalam proses pengembangan Game Edukasi Pengenalan Ekosistem pada mata pelajaran IPA SMP berbasis mobile ini, pengguna dapat menggunakan aplikasi ini dengan mudah. Aplikasi ini dibuat agar siswa lebih gampang belajar sambil bermain. Isi Aplikasi ini juga sudah disesuaikan dengan tema pada mata pelajaran IPA SMP kelas VII dan telah disetujui oleh guru pengajar pada sekolah yang diujicobakan. Aplikasi game edukasi ini.

\section{Testing (Pengujian)}

Setelah aplikasi selesai dibuat maka langkah selanjutnya yaitu melakukan pengeteran sistem dan uji coba pengguna dimana pengetesan sistem ini bertujuan untuk mengetahui apakah aplikasi game edukasi ini sesuai dengan yang dirancang dan berfungsi keseluruhan atau tidak.

\section{Distribution (Pendistribusian)}

Setelah melakukan pengujian, tahap selajutnya adalah distribution. Tahap ini merupakan tahap pengadaan aplikasi. Aplikasi ini setelah melakukan proses build dalam bentuk .Apk dengan pengaturan menggunakan Unity $3 D$.

\section{PENUTUP \\ Kesimpulan}

Berdasarkan hasil penelitian, aplikasi game edukasi ini dapat dikembangkan dan dapat dijalankan dengan menggunakan metode MDLC (Multimedia Development Life Cycle). Dengan demikian aplikasi ini telah dapat digunakan dengan Materi Ekosistem (Darat, Air, dan Buatan) dan aplikasi ini telah mempermudah pembelajaran terutama pada SMP $\mathrm{Kr}$. Irene Manado kelas VII.

\section{Saran}

Saran untuk penelitian selanjutnya yaitu: 1) Menambahkan materi lain juga sangat bermanfaat untuk membuat aplikasi menjadi lebih menarik; 2) Ukuran aplikasi perlu dipertimbangkan selama proses pembuatan aplikasi untuk bisa memaksimalkan ukuran hasil akhir aplikasi; 3) Diharapkan juga untuk kedepannya game ini dibuat bisa tersambung ke internet.

\section{DAFTAR PUSTAKA}

Anonim. (2012). World Health Statistic. WHO Library Cataloguing in Publication Data.

Bundu, P. (2006). Penilaian Keterampilan Proses dan Sikap Ilmuwah Dalam Pembelajaran Sains Sekolah Dasar - jakarta: Depdiknas.

Dewi. (2012). Pengembangan Game Edukasi Pengenalan Nama Hewan Dalam Bahasa Inggris Sebagai Media Pembelajaran Siswa Sd Berbasis Macromedia Flash. Yogyakarta: Universitas Negeri Yogyakarta. 
A. Mewengkang ${ }^{1}$, I. R. H. Tangkawarow ${ }^{2}$, \& H. Kasehung ${ }^{3}$

Halim., M. (2013). Pembuatan Game "The Last Mission" Dengan Menggunakan Fps Creator. Yogyakarta:: Amikom Yogyakarta.

Indriyanto. (2006). Ekologi Hutan. Jakarta: Penerbit PT Bumi Aksara.

Jasson. (2009). Role Playing Game (RPG) Maker, Ari Pidekso,. Yogyakarta: Penerbit ANDI.

Komputer Wahana. (2014). Mudah Membuat Game 3 Dimensi Menggunakan Unity 3d-By Wahana Komputer. Yogyakarta:: Andi.

Prastowo, A. (2014). Pengembangan Bahan Ajar Tematik. Jakarta: Kencana.

Purwoko, A. (2012). Pengelolaan Ekosistem dan Lingkungan. Medan.: Universitas Sumatera Utara. Medan.

Samsul, A. H. (2016). Game Edukasi Cepat Tepat Dengan Metode Finite State Machine (Fsm) Pada Smartphone. Malang: Universitas Islam Negeri Maulana Malik Ibrahim.

Sutopo, A. (2012). Teknologi Informasi Dan Komunikasi Dalam Pendidikan. . Yokyakarta: : Graha Ilmu.

Wahono, S. (2012, Januari 08). Aspek dan Kriteria Penelitian Media Pembelajaran. Retrieved from http//romisatriawahono.net/
Jurnal Sains dan Teknologi, Universitas Negeri Manado http://ejournal.unima.ac.id/index.php/efrontiers

Widodo, P. P. (2011). Menggunakan UML. Bandung.: Penerbit Informatika.

Wifda, A. R. (2015). Pengembangan Game Edukasi Lingkungan Berbasis Android. Yogyakarta: Univesitas Negeri Yogyakarta.

Zulfadli Fahrul Rozi. (2010). Menggunakan UML. Bandung: Informatika.

\section{RIWAYAT HIDUP PENULIS} Alfrina Mewengkang, S.Kom., M.eng. Lahir di Manado, 15 Januari 1989. Staf pengajar di Universitas Negeri Manado. Studi S1 Sistem Informasi Universitas Kristen Satya Wacana, Salatiga, lulus tahun 2010. S2 Teknologi Informasi Universitas Gadjah Mada Kota Yogyakarta, lulus tahun 2013. 